\title{
An intercultural theory of international relations: How self-worth underlies politics among nations
}

JÖRG FRIEDRICHS

Department of International Development and St Cross College, University of Oxford

Email: joerg.friedrichs@qeh.ox.ac.uk

Has been published by the journal International Theory, Vol. 8 No. 1, pp. 63-96.

Published version available at http://dx.doi.org/10.1017/S1752971915000202

This version is very similar to, though not identical with, the published version.

\begin{abstract}
This article introduces an intercultural theory of international relations based on three distinctive ways of establishing self-worth: honor, face, and dignity. In each culture of self-worth, concerns with status and humiliation intervene differently in producing political outcomes. The theory explains important variation in the way states and nations relate to members of their own culture of self-worth, as well as members of other such cultures.
\end{abstract}

Keywords: recognition; honor; face; dignity; status; humiliation 
Self-worth is the ultimate human motivator. When people pursue power and plenty, or knowledge and virtue, they do it to be someone. Self-worth operates at the individual level, but also vicariously at group level. Even before fully grasping the ideas of nation and state, my son was delighted when Germany won the World Cup. He also understood that it was important not to hurt the feelings of his English classmates whose team had dropped out. It would be surprising if, in the world of adults, self-worth did not profoundly affect social relations at any level, from families to peer groups and from nations to civilizations.

International relations scholars have started to acknowledge this, highlighting the importance for states and nations of recognition, status, and respect. Few have realized, however, that there are important cultural differences in the pursuit of self-worth. In some cultures, honor is the dominant pursuit. In others, saving face is the main concern. Yet other cultures profess the primacy of human dignity. As this article shows, it makes an enormous difference not only for people and groups but also for states and nations, as well as the relations between them, which of these distinct forms of self-worth is predominant: honor, face, or dignity.

A theoretically grounded understanding of such differences can explain variation in processes and outcomes. Whether states seek honor, face, or dignity makes a difference for the way they relate to fellow members of their own culture of self-worth, as well as members of other such cultures. This basic insight enables an intercultural theory of international relations that is sensitive to really existing cultures of self-worth. Intercultural theory does not postulate cultural monoliths, nor does it exclude the possibility of change, but it does take the recalcitrance of historically developed cultures more seriously than other constructivist approaches. It sees culture as "sticky" and capable of producing consequences that we ignore only at our peril. It follows Durkheim in seeing it as often more difficult to alter social facts than to change our physical environment. Modern technology can move mountains and connect us globally, but can it remove visceral affinities and hostilities, and engineer harmony? 
The fundamental premise is that all people and groups, including nations and states, crave for recognition of self-worth, but they do so in different ways. Understanding the differences between the cultural logics of honor, face, and dignity enables the scholar not only to understand but also to predict what happens when countries belonging to the same culture, as well as countries belonging to different cultures of self-worth, meet in international relations, and to subject these predictions to suitable tests and plausibility probes.

The theory's five hypotheses give pride of place to status and humiliation as mediating factors, or intervening mechanisms. While it is hardly controversial to say that status is an important concern for states, it matters differently for honor, face, and dignity cultures. The same applies to humiliation. One result is that dignity cultures often fail to understand the hurt they cause in honor and face cultures. As the theory shows, concerns with status and humiliation mediate the social and political impact of honor, face, and dignity.

Far from invalidating other international relations theories such as realism or liberalism, the theory complements them. It sometimes provides deeper explanations for familiar phenomena and sometimes captures phenomena that other theories have difficulties accounting for. As the article will demonstrate, intercultural theory can address questions such as the following: Why are Chinese-Japanese and Korean-Japanese relations more difficult than French-German and Dutch-German relations? Why does Russia appear to be more concerned with status, and China more susceptible to humiliation and resentment, than western countries?

After a survey of relevant scholarship (Part 1), I outline honor, face, and dignity culture in general terms and show how concerns with status and humiliation intervene differently to produce social and political outcomes (Part 2). Subsequently, I derive hypotheses about international relations among members of each culture (Part 3), as well as between states belong- 
ing to different cultures of self-worth (Part 4). After a section problematizing shifts between levels of analysis (Part 5), I conclude with a summary and some further thoughts.

\section{The Lay of the Land}

In recent years, there has been no shortage of scholarship devoted to self-worth in international relations. This includes a burgeoning literature on recognition and status, scholarship about national honor, and Lebow's cultural theory of international relations. While all of this scholarship is highly pertinent to my theory, it mostly hails from western experience and operates at high levels of generality, rather than allowing for the possibility that people and groups, as well as nations and states, crave recognition in fundamentally different ways.

To begin with, there is a burgeoning literature on recognition. Harking back to Hegel (1807), thinkers like Fukuyama (1992), Taylor (1994), and Honneth (1995) have established the "struggle for recognition” as a source of social conflict and human progress. In their footsteps, international relations scholars like Ringmar (1996), Wendt (2003), Haacke (2005), and Greenhill (2008) have discussed the quest for recognition as a central feature of international relations and as a driver of historical change. Adding to this literature, Reinhard Wolf has made seminal contributions on the importance of respect (2011, 2012, 2015)

In 2012, the philosopher Axel Honneth included a chapter on international recognition in his latest book (2012, 137-152) and contributed to edited volumes on recognition in social conflict and international relations (Smith and O'Neill 2012; Lindemann and Ringmar 2012). Since then, scholarship about international recognition has exploded. It includes, but is not limited to, a broad survey from legal, political, sociological, and moral perspectives (Agné et al. 2013), a journal special issue (Brincat 2014), and an edited volume (Daase et al. 2015). In 
February 2015, at the annual convention of the International Studies Association, I counted as many as fourteen papers and one roundtable dedicated to the topic.

Rooted in philosophy, the literature on recognition is universalizing and optimistic. Most authors see recognition as a mechanism leading to social and moral progress. They assume expanding circles of recognition that ultimately lead to recognition for everyone, everywhere. Wendt (2003), for example, postulates a Hegelian teleology of universal recognition. Only time can tell, but what if there are fundamental differences in the way people crave and award recognition, both over time and across cultures? What if the very idea of universal recognition is contingent on liberal hegemony and its material foundations (Morris 2015)?

Another relevant literature deals with status in international relations. T.V. Paul et al. (2014) have recently consolidated this literature, building upon previous scholarship about status in great power politics (Larson and Sevchenko 2010; Volgy et al. 2011) and, most notably, warfare (Wohlforth 2009). There are clear linkages connecting the literature on status with scholarship about recognition. For example, Lindemann (2010, 2014) claims that misrecognition of status is a decisive cause for war and only recognition can lead to lasting peace. ${ }^{1}$

The present article draws on one particular branch of the status literature, namely scholarship about status inconsistency (Volgy et al. 2011) or status anxiety (Renshon 2016). Status anxiety arises when an actor feels deprived of the status it feels entitled to (Gurr 1970), or when an actor is unwilling to cave in to what it sees as the inflated status claims of an upstart (Onea 2014). Among states, status anxiety may lead to intense rivalry and even war (Lebow 2010, 2015; Renshon 2016). Relations are likely to be more peaceful and amicable when states share an understanding of international status hierarchy (Wohlforth 2009).

\footnotetext{
${ }^{1}$ For a survey of the literature on status and reputation as motives for war, see Dafoe, Renshon, and Huth (2014).
} 
Modernist western scholars dominate both the literature on recognition and scholarship about status. While acknowledging that the quest for status recognition does not only serve material interests but also social and perhaps even emotional needs, they deemphasize outmoded notions of self-worth such as honor. This is in line with an exalted tradition highlighting the obsolescence of honor (Montesquieu 1750; Schumpeter 1951; Berger 1970; Taylor 1994).

Not everybody agrees. For a century, isolated voices have argued for the enduring importance of honor, notably in international relations (Perla 1918; Best 1982; O'Neill 1999; Donelan 2007). One author asserts that, "for all the talk of honor's obsolescence, it clearly remains central to the waging of war. In this sense, nothing has changed since the age of Achilles” (Robinson 2006). Another author proposes an Honor War Theory that harks back to ancient warrior codes and suggests that honor ethics can be "respectful, fair minded, and deadly," arguing that non-western combatants beholden to ancient codes of chivalry would prefer such treatment (Demetriou 2013, 311). The claim is somewhat plausible if we consider current practices of non-recognition in asymmetrical warfare, where the humanity of enemy combatants does not count for much if anything (Delori 2014; Lindemann 2014).

The fact that honor sounds less progressive than dignity is no reason to dismiss notions like national honor as analytical concepts for the study of international relations. What is more, just because honor is obsolete in the west does not mean that it is obsolete everywhere (Stewart 1994; Iliffe 2005; Weiner 2013). The same applies to face, including national face (Hu 1944; Goffman 1955; Gries 1999). While for western societies the transition from honor to dignity may be largely completed, countries like Russia and India remain stuck in the transition. There are entire world regions, from the Middle East to Africa and from Asia to the Pacific, where culturally specific notions of honor and face remain salient. 
In his seminal Cultural Theory of International Relations, Lebow (2008) acknowledges the importance of honor. Relying on Greek and other classical western authors, Lebow posits honor as a fundamental psychic motivator alongside material interest. Following Thucydides and Plato, he cautions that the hypertrophic pursuit of honor and interest is destructive unless reason is in control. In other words, reason is required to hold honor and interest in equilibrium. When that equilibrium is off balance, fear takes over and unleashes a ruinous contest for security and survival. Lebow applies this elegant model to 2,500 years of western history, suggesting that contemporary scholars underappreciate the quest for honor.

The model is sufficiently multidimensional to allow for cultural change, but Lebow fails to contemplate the possibility that honor culture may not be the only culture of self-worth. He also fails to appreciate that western manifestations of honor such as the US invasion of Iraq in 2003 have become the exception rather than the rule. ${ }^{2}$ Honor cultures, where they still exist, are now largely outside the west. Yet, Lebow fails to analyze non-western cultures of selfworth, apart from a digression on inter-war Japan as a misguided status-seeking “parvenu power,” not unlike Hitler’s Germany and Mussolini’s Italy (pp. 397-417).

While fully appreciating the value of Lebow's western-centric cultural theory, my aim is to push the envelope and offer an intercultural theory of international relations. Following the intuition that people crave recognition in different ways, I have sought out theories of selfworth allowing for such variation. The best framework I could find comes from a somewhat obscure and little-known branch of social and personality psychology. As the next section suggests, the framework holds great promise for intercultural theory.

\footnotetext{
${ }^{2}$ George W. Bush may have invaded Iraq for honor; but then Clinton must have had some other motive not to invade Iraq, and Obama to withdraw from the county.
} 


\section{Three Cultures of Self-Worth}

Recent scholarship in social and personality psychology suggests a distinction between three cultures of self-worth: honor, face, and dignity (Leung and Cohen 2011). While these cultural "logics” are theoretical constructs, experimental studies show their empirical relevance and explanatory power. Kim, Cohen, and Au (2010) have found observable differences in behavior between dignity and face cultures. People living in dignity cultures follow different ways of absorbing the judgment of others from people living in face cultures. In a dignity culture like the USA, people display a studied indifference to the judgments of peers, whereas in a face culture like Hong Kong they absorb such judgments, and especially public representations of their worth, into their self-definition. In another study, Kim and Cohen (2010) have found that Americans hailing from East Asian face cultures are more concerned than AngloAmericans with the way others see their strengths and weaknesses.

Aslani et al. (2013) have applied the tripartite framework of honor, face, and dignity to the more "political” field of conflict management and business negotiation. This is in line with findings from intercultural diplomacy, where face and honor play important roles (Cohen 1997). Following the same tack, it is possible to move from social and personality psychology to political science and international relations, and from the individual and small-group level to the national and further to the international level (see Text Box).

Although the literature from social and personality psychology focuses on the self-worth of individuals acting in small-group environments, Wolf (2012) has shown that the framework can "travel” to interactions between larger social aggregates, including states. Insofar as people strive not only for personal but also for group recognition, or “corporate recognition" (Wendt 2003, 515), it is possible to study notions such as "the honor of the family" and "the 
honor of the clan” (Weiner 2013). The idea of national honor has been commonplace for a long time and has received scholarly attention (Perla 1918; Best 1982; O'Neill 1999; Donelan 2007). Specifically in the East Asian context, the same applies to "group face" and "national face” (Hu 1944; Gries 1999; Kádár, Haugh, and Chang 2013; Erickson 2014).

For more on the question of levels of analysis, see the section before the conclusion.

Text Box: Levels of analysis

\section{Honor, face, and dignity}

In what follows, I go beyond Leung and Cohen (2011) and develop the conceptual triptych of honor, face, and dignity into a formal matrix. In dignity cultures, people understand selfworth as intrinsic to the subject and inalienable. In face cultures, they see it as determined by the reference group, hence extrinsic and alienable. In honor cultures, they view it as internalized yet contestable when significant others fail to pay respect (Table 1).

\begin{tabular}{|l|c|l|l|}
\cline { 2 - 4 } \multicolumn{1}{c|}{} & Inalienable & Contestable & Alienable \\
\hline Intrinsic & Dignity & & \\
\hline Internalized & & Honor & Face \\
\hline Extrinsic & & & \\
\hline
\end{tabular}

Table 1: Three cultures of self-worth 
Let us begin with honor, as the most ancient of the three logics (Nietzsche 1994 [1887]; Finley 1954; Bowman 2012). According to an authoritative definition, honor is "the value of a person in his own eyes, but also in the eyes of his society. It is his estimation of his own worth, his claim to pride, but it is also the acknowledgement of that claim, his excellence recognized by society, his right to pride” (Pitt-Rivers 1965, 21). As a convenient shorthand, another author defines honor as "the right to respect" (Stewart 1994, 21).

Honor cultures are troubled because honor is ambivalent. It is neither intrinsic nor extrinsic, but internalized. At the same time, it is neither entirely alienable nor entirely inalienable, but contestable. It is never quite clear whether honor resides in the honorable person, or if that person is honorable only because others have bestowed honor on him (with due apologies, “men of honor" are indeed typically men). On the one hand, honor culture socializes men of honor into claiming self-worth as droit de regard. On the other hand, significant others may challenge their honor at any time. As an effect of this inherent contradiction, men of honor treasure their honor as something they may, nay must, defend at all cost.

In other words, honor cultures assign self-worth as a status function (Searle 2010). They endow certain people with a claim for respect. At the same time, they impose on these people an injunction to jealously guard their “rightful position” (Wolf 2011, 106). They expect men of honor to take pride in their status, strive for distinction, and react with forceful indignation to any lack of respect. Hence, honor is conditional on role fulfilment. When significant others find that you fall short of what the honor code demands, then it is on you to prove them wrong. This injunction of “toughness” makes honor cultures agonistic, confrontational, and troublesome. Men of honor become furious when they feel that significant others might doubt 
what society has inculcated in them as their claim for pride, and this fury is what Plato had in mind when identifying thumós as the characteristic of honorable manliness. ${ }^{3}$

Dignity is radically different. The literature often defines it as "the conviction that each individual at birth possesses an intrinsic value at least theoretically equal to that of every other person” (Ayers 1984, 19; cited recently in Lee, Leung, and Kim 2014, 317). By implication, self-worth grounded in dignity is, or should be, intrinsic and inalienable.

In a dignity culture, your self-worth is your birthright. Nobody must take it away from you. There is a human dignity innate in every human being regardless of rank or merit. Everyone is entitled to such dignity no matter her race, class, or gender. "All human beings are born free and equal in dignity and rights” (Universal Declaration of Human Rights, 1948, Article 1). "Human dignity shall be inviolable” (German Constitution, 1949, Article 1). In some way, this resolves the contradictions inherent in honor culture. Reframing self-worth as intrinsic and inalienable leads to a measure of ontological security greater than in honor cultures, where people must constantly worry that others might deprive them of respect. ${ }^{4}$

Alas, there is another problem. Dignity is inalienable in theory, but we may lose it in practice. For example, we may lose dignity because of crippling inequality, or because significant others mob or bully us. Thus, the inalienability of dignity is aspiration rather than reality. Dignity societies suffer from the contradiction that dignity is supposed to be inalienable, yet is utterly fragile and like all other forms of self-worth depends on recognition. ${ }^{5}$

Face, or "the social anchoring of self in the gaze of others" (Qi 2011, 280), is a stable solution to the contradictions of honor and dignity. According to Ho (1976, 883), face is "the re-

\footnotetext{
${ }^{3}$ Like Homer and Plato, but unlike Fukuyama (1992), I see thumós as an aristocratic virtue.

${ }^{4}$ The notion of respect appears closer to honor than to dignity (cf. Wolf 2011).

${ }^{5}$ Given this contradiction, I remain unconvinced by Hegelian arguments that universal dignity is a stable end state (Fukuyama 1992; Wendt 2003).
} 
spectability and/or deference which a person can claim for himself from others, by virtue of the relative position he occupies in his social network and the degree to which he is judged to have functioned adequately in that position as well as acceptably in his general conduct.” Contrary to dignity, face culture frames self-worth as extrinsic and alienable.

In a face culture, your worth belongs to your community, which has bestowed it upon you and can take it away. In the final analysis, it is beyond your control and you should not internalize it as belonging to you. You can do face-work (Goffman 1955, 1967) to improve your public persona, just as you can use makeup to embellish your visage, but what matters is the gaze of others. In a social setting, everyone can see your face except you. While your face is inseparable from your self-worth, you can never control the gaze of others.

Framing self-worth in this way is consistent but comes at a price in terms of personal autonomy. When people see themselves as owing their self-worth to others, they become loss averse and guard themselves carefully. They understand that their worth is beyond their purview, and they know how devastating a loss of face would be for them. Ancient codes like Japanese bushido pointed to ritual suicide as the ultimate way out (Benedict 2005 [1946]).

It is possible to align honor, face, and dignity with a stage model. Whereas honor culture thrives under conditions of weak and contested social hierarchy, face culture is typical of hierarchical societies sustaining dense agrarian populations in ancient times. Until recently, most of the world except for East Asia was in the thrall of honor culture.

In East Asia, there has been a transition from honor to face thousands of years ago. Even today, the societies found in the Far East - most notably in China, Japan, and Korea - favor such interdependent self-concepts (Aslani et al. 2013, 252-254). In recent centuries, there has been a similar transition from honor to dignity in the west. It will depend on our values whether and to what extent we understand such progression as progress. 
Even in the west, the transition from honor to dignity is fairly recent. In parts of the west, such as Latin America, the process remains incomplete. In Japan and Korea, a similar transition from face to dignity may be underway. In countries like Russia and India, where honor culture remains the fallback option when dignity fails, the process is inchoate. Reversals are possible, and despite the ascendancy of dignity an end of history is not in sight.

Dignity culture has an elective affinity with liberal democracy, whereas honor culture tends to come with authoritarian forms of rule (Montesquieu 1750; Schumpeter 1951). Face culture is somewhere in between, abetting authoritarian relations of social hierarchy but also capable of democratic transitions, as demonstrated by Japan, South Korea, and Taiwan.

\section{Status and status anxiety}

Living under the spell of honor, face, or dignity makes a tremendous difference for people’s lifeworld. Yet, in and of themselves cultures of self-worth hardly have the power to produce social and political outcomes. They generate outcomes through mediating factors such as status, as well as status anxiety. In each culture of self-worth, status and status anxiety intervene, or fail to intervene, in characteristic ways to shape relations and make them either positive and stable or difficult and unstable, thus producing social and political outcomes.

Status, or "the position in a social hierarchy” (Sauder, Lynn, and Podolny 2012, 268), plays a greater role in honor and face cultures than in dignity cultures. The reason is that dignity "relates to the intrinsic humanity divested of all socially imposed roles or norms. It pertains to the self as such, to the individual regardless of his position in society” (Berger 1970, 342). It follows from this very concept that status does not, or should not, matter for the determination of self-worth. That does not mean that people in dignity cultures do not strive for distinc- 
tion, but dignity culture deflates the importance of status for self-worth. By implication, problems of status anxiety should be of limited importance as a source of conflict.

In honor cultures, where self-worth is contingent on the fulfilment of role expectations in a social hierarchy (Taylor 1994), status is paramount. At the bottom of the pack, honor equals shame (typical for marginalized women). The greater a man, the greater his pride. A "man of honor" derives his self-worth primarily from recognition by the other members of his honor group, which consists of all those people of equivalent status who are his significant others. Hence, contestation over honor is particularly rife among equals, or peers. ${ }^{6}$

This is where status anxiety comes into play. As mentioned, status anxiety arises when an actor feels deprived of the status it feels entitled to (Gurr 1970). Among individuals, status anxiety may lead to rivalry and conflict. Among states, it may even lead to war (Renshon 2016). Relations tend to be better, and conflict less rife, when there is a mutually agreed social hierarchy (Gould 2003). In systems based on honor, the hierarchy tends to be clear except for the fact that peers rely on their honor group for recognition, exacerbating status anxiety. The result is that social relations are more difficult and less stable among peers.

Indeed, not everyone can offend a man of honor in the same way. If you are a man of honor, people of lower status should be unable to hurt you because they are beneath yourself. ${ }^{7}$ People of higher status may hurt you, but you cannot lash back at them, essentially for the same reason, only that this time you are the one in the subaltern position. When challenged by a rough equal, however, you must be ready to stand up for your honor and demand satisfaction. Take for example the macho code of dueling. Under that code, only equals were supposed to

\footnotetext{
${ }^{6}$ The Hegelian idea that masters depend on slaves for recognition misses the point that, for individuation and self-worth, masters need recognition from other masters and not from slaves. Short of slave rebellion, it is enough for them to rely on the recognition of peers. ${ }^{7}$ Consider how Odysseus deals with the insubordination of Thersites in Iliad II, 211-277.
} 
demand and provide satisfaction because "the full code of honor only applies among those who share the same status in the hierarchy” (Berger 1970, 340).

In a face culture, your face denotes your place. Your community has given it to you, and your community can take it away. This has two effects. First, it yields clear and consistent status hierarchies that rest on group consensus. People will know their place. Second, status anxiety is enormous but cannot destabilize relations. People will know that they are vulnerable to misrecognition by their entire group. Even an inferior can violate the face of a superior, although to a lesser degree. A boss in a Korean company will feel devastated when losing face with her employees (Kim and Nam 1998). When face is in jeopardy, people will work discreetly towards rehabilitation. Defiance is counterproductive because people do not own their face. Instead, their best hope is appealing to the forbearance of the group on which they depend for recognition. Failing that, they may settle for lower status or fall into despair.

In short, status is more salient for honor and face than for dignity cultures. In honor cultures, hierarchy is like a "pecking order” with “cockfights” rife among status-anxious rivals because the honor code requires defending honor against real or perceived challenges from peers. In face cultures, hierarchy is engrained in the collective consciousness of the group and status anxiety cannot burst into conflict because people must know their place. In dignity cultures, self-worth is a birthright so status and, by implication, status anxiety should matter less.

\section{Humiliation and resentment}

Another mechanism linking self-worth with social and political outcomes is humiliation and resentment. Humiliation arises when an actor is unable to counteract misrecognition. Misrecognition follows a different logic in different cultures of self-worth, and this in turn has im- 
plications for how humiliation may either destabilize social relations due to simmering resentment, or end with the rehabilitation of victim and perpetrator. Following Nietzsche (1994 [1887]) and Scheler (1994 [1912]), resentment is a negative emotion whereby an actor takes, or mistakes, another actor's superior power as a sign of moral inferiority, nurturing a rancorous and revengeful attitude. This can undermine the quality and stability of relations. ${ }^{8}$

Like status and status anxiety, humiliation and resentment intervene differently in different cultures of self-worth to affect the quality and stability of social relations. In honor cultures, those claiming higher status may humiliate those of lower status with relative impunity. Hence, “men of honor” tend to show little regard for feelings of humiliation and shame among inferiors. However, this may misfire badly. Even though those humiliated may be unable to immediately fight back, defying the debasement of their self-worth and claiming equal status, they may become resentful. Once they acquire the resources and strength necessary for defiance, the backlash is then going to be all the more acrimonious. Hierarchies are subject to change. Inferiors may rise. Superiors may decline. When that happens, those humiliated may seize the opportunity to settle scores with those who used to humiliate them. In this way, humiliation and resentment are a significant source of conflict in honor cultures.

In face cultures, by contrast, humiliation and resentment should be relatively rare. Since people depend on their entire reference group for communal recognition, they are loath to humiliate or shame others, including their inferiors. Everybody sits in a glasshouse where throwing stones can be dangerous, so humiliation should be less likely to occur. What is more, people in a face culture know that they depend on their reference group for the restoration of their social reputation when, for whatever reason, a humiliation has occurred. They are therefore more likely to humbly plea for rehabilitation than to nurture a resentful attitude.

\footnotetext{
${ }^{8}$ See also Oldmeadow and Fiske (2012); Wolf (2013); Fassin (2013); Ure (2015)
} 
However, this applies only to people embedded in groups. The logic of face operates differently for groups interacting with other groups. While an individual is almost completely at the mercy of her reference group for the determination of her worth, a social group has ways to stabilize self-worth internally. A villager losing face falls into a bottomless pit, whereas a village can recover part of its collective self-worth by means of parochial discourse and other practices affirming the communal self. At least in part, collective face is intra-communal and thus not only extrinsic but also intrinsic. Under such circumstances, inflating the internal selfworth of the group is the only defense mechanism available against the fundamental alienability of face. Resentment may arise and can lead to tremendous dislocation. It may fester on as visceral hatred against any source of humiliation, destabilizing future relations.

In a dignity culture, you do not depend for your self-worth on other people or groups but on society in general. From such a dignity perspective, obsession with status is pathological. Insofar as dignity is intrinsic and inalienable, “everyone shares in it” (Taylor 1994, 27). This implies that, when somebody has violated your dignity, you can reaffirm it and count on society to reintegrate you. You may insist, and others will have to agree, that your dignity is inalienable. Violators may face social sanctions and/or legal consequences, but even they can expect reintegration. The restoration of social harmony should come rather easy. ${ }^{9}$

In short, humiliation has more severe consequences for social relations in honor and face cultures than in dignity cultures. In honor cultures, humiliation of inferiors is frequent and leads to resentment, jeopardizing future relations. In face cultures, humiliation is relatively rare but may lead to simmering resentment, notably among groups. In dignity cultures, humiliation is, or should be, followed by resocialization, rehabilitation, and reintegration.

\footnotetext{
${ }^{9}$ Western dignity culture appears to be currently in a metamorphosis to a new regime where society assigns victimhood as a somewhat attractive subject position, relegating perpetrators to permanent contumely. For more on this troubling development, see the conclusion.
} 


\section{Intra-Cultural IR}

Subscribing to a culture of self-worth has implications for social aggregates including states. This section covers international relations (IR) among states belonging to the same culture. We may call this intra-cultural IR. As we will see, IR have a distinct flavor for each culture. This is not to deny internal variation, as between the Middle East and Africa for honor cultures, China and Japan for face cultures, or the USA and Europe for dignity cultures.

\section{Honor cultures}

As the most ancient form of self-worth, honor culture remains the default condition in most of the world. We may assume that all those societies that have not transitioned to face culture millennia ago, or to dignity culture more recently, remain honor cultures.

Historical examples include the Old South of the United States (Wyatt-Brown 1982; Ayers 1984) and traditionalist pockets in Mediterranean Europe (Péristiany 1966, for a vast literature). In these and similar cases, such as Latin America, traces of "southern" honor culture persist despite various forms of modernization superseding them (for the USA, see Nisbett and Cohen 1996; Vandello, Cohen, and Ransom 2008). Historically, US Presidents and soldiers from the South have been more martial and honor-bound than those hailing from elsewhere (Fry 2002; Wyatt-Brown 2005). One author argues that Texan honor culture has exacerbated President George W. Bush’s response to 9/11 (Saurette 2006, 510-513).

As these cases illustrate, transitions from honor to dignity may be incomplete. In India, strong egalitarian norms and a commitment to dignity going back to the independence struggle coexist with an acceptance of, and pride in, stark forms of inequality such as caste (Jaffrelot 2011). At the international level, this is reflected in India's oscillation between trying to be a 
developing country leader on the one hand, and aspiring to become a "normal" great power on the other (Nayar and Paul 2003; Paul and Shankar 2014). Even more notoriously, national honor plays a crucial role for Russia despite countervailing tendencies (Tsygankov 2012).

Scholars like Stewart (1994) and Weiner (2013) see the Middle East as the hotbed of honor culture par excellence. While at the doctrinal level Islam emphasizes equality and opposes discrimination based on tribe or race, this applies to Muslim believers only. There is an elevated sense of self-worth vis-à-vis “unbelievers”, including people seen as heretics. What is more, Arab, and especially Bedouin, notions of honor have permeated Middle Eastern societies to such an extent that Islam has become deeply intertwined with honor culture. ${ }^{10}$

In line with the cultural logic of honor outlined in the last section, we should expect a status hierarchy that resembles a pecking order, empowering superiors at the expense of inferiors. Further, we should expect status anxiety to be an important source of conflict, especially among equals. Finally, we should expect international relations among honor cultures to be rife with conflict when humiliation and resentment are at play (Hypothesis 1).

\section{Hypothesis 1: Relations among honor cultures}

a) Status hierarchy empowers superiors at the expense of inferiors.

b) Status anxiety is an important source of conflict among equals.

c) Conflict is rife when those humiliated claim equal status.

\footnotetext{
${ }^{10}$ Historically, Sub-Saharan Africa has also been home to tribal honor cultures. Despite the
} spread of Christianity and Islam, they remain widely recognizable (Iliffe 2005). 
It is not necessary to go deep into colonial history to see that honor culture empowers those of superior status at the expense of subalterns. In the heydays of western colonialism and imperialism, European countries had only started their transition from honor to dignity culture. Especially in colonial affairs, aristocratic honor codes held sway. More recent examples include the way Libya under Ghaddafi acted in Chad and sub-Saharan Africa, or the way Arabdominated Sudan is dealing with recently independent, “black African” South Sudan.

Understanding the states and societies of the Middle East as exemplars of honor culture may contribute to explaining the fact that international relations in that region are particularly tense and conflict-prone (Solingen 1998). Since honor codes require the settlement of scores among rivals, status anxiety is a significant source of conflict potential. Given the importance of peers for the determination of honor, relations are particularly unstable among equals.

They are more stable when there is consensus on which party has higher status. South Asia is a good example for this. In line with the cultural logic of honor, relations are more difficult among rough equals, as between India and Pakistan, than when there is a clear asymmetry of status, as between India and Bangladesh or between India and the Maldives.

Honor cultures of higher status tend to show little regard for those whom they deem of inferior status. This may lead to humiliation and resentment, which may in turn lead to conflict further down the line, especially when those humiliated claim recognition of equal status. The history of Pakistan's humiliation at the hands of India is a good example for this. After scores of military defeats and political setbacks, Pakistan is struggling to keep up with India. Nevertheless, Islamabad insists on parity and does not relent in its pursuit of revanchist goals (Fair 2014). Also in line with the theory, there seems to be little awareness among Indian leaders that treating Southeast Asian countries as part of "Greater India” comes across as patronizing and may lead to resentment rather than sympathy (Jaffrelot 2011, 721, 738). 
Claims for status equality can be a matter of self-assessment. Especially honor cultures sometimes claim equal status on the face of enormous disparities. Take for example North Korea's reckless defiance of vastly superior opponents. Muslim countries are another case in point. Islam deemphasizes status distinctions among Muslims, only to reemphasize them between Muslims and non-Muslims. The community of Muslim believers, or ummah, claims to possess an uncorrupted version of divine revelation. Islamic doctrine has it that other "religions of the book" such as Christianity and Judaism, which have a corrupted version, deserve subordinate status if they acknowledge Muslim supremacy, whereas unbelievers and idolaters deserve little or no recognition (Y. Friedman 2003). In this view, Islam is the only true religion and constitutes the highest form of civilization. While many Muslims do not share this view, it leads to an elevated sense of status among those who subscribe to it, making way to outrage when Muslims find themselves in an inferior position. Not only individual Muslims but also their leaders, including Islamic states, experience subaltern status as inconsistent with their elevated sense of self-worth and occasionally react in insurgent ways.

\section{Face cultures}

Although face cultures are not exclusive to East Asia (Nwoye 1992), the most clear-cut cases are China (Gries 1999, 2004; He and Zhang 2011; Kádár, Haugh, and Chang 2013) and Korea (Hahn and Hatfield 2011; Hatfield and Hahn 2014). Another interesting case in point, although somewhat less studied, is Japan (Morisaki and Gudykunst 1994).

Notions like "group face” and "national face” come natural to East Asian authors. In a seminal article, Hu (1944, 48, 50, 59) gave various examples of "face” where the referent object was the nation rather than the individual: (1) The appeasement policy under Neville Chamberlain had led to a loss of British face in the eyes of the Chinese. (2) Chinese locals were 
concerned about losing "the face of their country" when dealing with Americans. (3) During the Sino-Japanese war, the Chinese saw the British as "padding China’s face.”

In line with the logic of "group face”, as outlined above, we should expect international relations among face cultures to be shaped by a status hierarchy that rests on norms and understandings shared by the reference group. The participants should be more likely to "know their place” and hence be less susceptible to status anxiety. Humiliation and resentment should be unlikely, but seriously destabilize relations when they occur (Hypothesis 2).

\section{Hypothesis 2: Relations among face cultures}

a) Status hierarchy is clear and rests on group consensus.

b) Clear and consensual hierarchy mitigates status anxiety.

c) While unlikely, humiliation may seriously destabilize relations.

There are two reasons for why relations among face cultures should be more positive and stable than among honor cultures. First, the status hierarchy rests on understandings shared by the group and not on a pecking order that empowers superiors at the expense of inferiors and pitches peers against each other. Second, it is easy to see that, under such conditions, status anxiety is less likely to arise. As we have seen, understanding self-worth as extrinsic and alienable leads to clear and consistent status hierarchies. Under the logic of face, every participant relies for its self-worth on the entire reference group, which in the case of international relations consists of other countries. Given the clear hierarchy in a system based on face, leadership is often uncontested. Even rough equals do not live under the same expectation as under the logic of honor to assert their self-worth in competition against each other. 
There is a catch, however. While unlikely, humiliation and resentment may seriously destabilize relations further down the line. On the one hand, humiliation is unlikely to occur because face cultures are considerate and concerned with social harmony. Face depends on recognition not only from peers and superiors but also from inferiors. Accordingly, those of higher status are sensitive to feelings of humiliation even among those of inferior status. In the unlikely event that a humiliation does occur, however, it may seriously destabilize relations. When feeling humiliated, the face culture will mobilize patriotic discourse to stabilize itself. This may lead to aggressive posturing against the real or perceived source of humiliation. When retaliation is impossible, humiliation may fester on as visceral resentment. ${ }^{11}$

East Asian history is an ideal observatory for international relations among face cultures. Before the advent of western colonialism, there were five centuries of "Confucian long peace”, from 1368 to 1841 (Kang 2010; Kelly 2011). The international hierarchy was clear, with China as the Middle Kingdom surrounded by a "social hierarchy defined in cultural and civilizational terms” (Yongjin and Buzan 2012, 14-15). China, Korea, Vietnam, and Japan were at peace, whereas wars against non-Sinicized "barbarians” were common. Similar periods of “cultural peace” did not occur among the honor cultures of classical Greece, early modern Christendom, and in the modern Arab state system (Kelly 2011).

Compared to the precolonial situation, East Asia today is seriously out of kilter. The erstwhile hierarchy has collapsed and humiliations have occurred. It seems that East Asia would be far more stable were it not for the fact that China and Korea suffer from the shameful memory of Japanese occupation. Japan's relations with China, South Korea, and Taiwan have often been complicated by vitriolic standoffs and open outbursts of hostility (Gustafsson 2015; Wang

\footnotetext{
${ }^{11}$ Note the difference between face at the individual and at the group level, discussed in the section on humiliation and resentment: unlike individual face, group face is partly intrinsic.
} 
2012, 203-220). Even so, international relations among the face cultures of the Far East are more stable than those among the honor cultures of, say, the Middle East.

\section{Dignity cultures}

The idea of dignity, which has roots in the Christian folk belief that we are all God's children, has gained pride of place in the west. Its most characteristic expression is the understanding of human rights as universal entitlements. It is important to note, however, that parts of the west remain haunted by legacies of honor culture (Nisbett and Cohen 1996). Even the notion of face is certainly not alien to the west (Qi 2011). Despite such complications, contemporary western societies profess dignity and assert it whenever possible.

The notion of dignity mandates recognition of everybody’s intrinsic and inalienable selfworth. Whenever an individual or group feels misrecognized in their dignity, society is under an obligation to rectify the situation. It stands to reason that international relations among states who follow such august principles should be relatively stable. This is not to say that relations among dignity cultures are easy as conflict may arise for other reasons, but they should be better than relations among honor and face cultures (Hypothesis 3).

\section{Hypothesis 3: Relations among dignity cultures}

a) Relations among dignity cultures are relatively benign.

b) Status and status anxiety are of limited importance.

c) The same applies to humiliation and resentment. 
Understanding self-worth as intrinsic and inalienable deflates the importance of status and status anxiety. At least in theory although not always in practice, a position of power is no excuse for violating anybody’s dignity, nor does inferior status detract from one’s dignity. This almost empowers inferiors at the expense of superiors. Consider, for example, how small member states of the European Union play fast and loose with Germany, or how minor countries often give the runaround to the United States (Hoffmann 1968), whereas the same does not seem to happen with face cultures like China or honor cultures like Russia.

Relations among dignity cultures should also be fairly immune to humiliation and resentment. Whereas humiliation and resentment are predictors of trouble among honor and shame cultures, dignity culture deflates their importance. Given everybody’s intrinsic and inalienable dignity, it always is, or should be, possible to reintegrate the victims of past humiliations and even those who were the perpetrators. By way of an example, consider French-German and British-German relations after the War, and compare them to Chinese-Japanese and KoreanJapanese relations (Katzenstein 2005). Anti-Japanese resentment is clearly far more alive in East Asia than anti-German resentment in Western Europe.

This comes down to a reformulation of “democratic peace” in cultural terms. The reason for peaceful relations among democracies may be less the democratic nature of political rule, or even economic interdependence, than the fact that most of them are dignity cultures. More honor-bound democracies, like Pakistan and India, tend to be more belligerent.

\section{Operationalization}

How can we track the effects of cultures of self-worth on international relations? One route is to derive behavioral indicators from the hypotheses. For example, face cultures of higher sta- 
tus should be eager to avoid humiliating face cultures of lower status. Honor and dignity cultures, by contrast, should not show the same consideration for subalterns. Another route is to study discourse. For example, if it is true that status anxiety is of particular concern to honor cultures, as suggested by Hypothesis 1, then this should show in public speeches by leaders, diplomatic exchanges, archival documents, and memoirs of decision makers. Third, one may investigate whether and to what extent states undertake costly actions for the sake of selfworth that are otherwise hard to explain. For example, one may examine the conditions under which honor cultures escalate crises with other honor cultures into war, even when peace would be more beneficial; or the conditions under which dignity cultures avoid escalating crises with other dignity cultures into war, even when doing so would be beneficial. ${ }^{12}$

Qualitative approaches will be the method of choice in most cases. More often than not, researchers will conduct single and comparative case studies, and/or discourse analysis. Careful process tracing can reveal whether and to what extent the causal mechanisms suggested by the theory are at play, and how they interact with explanations sourced from other theories. To capture the causal complexity characteristic of the real world, researchers should always keep an open mind for alternate variables and related interaction effects.

Quantitative tools can support such research, but only with some qualifiers. Multivariate techniques of various kinds, including regression analysis, can be appropriate for hypothesis testing, but they require careful conceptualization and specification of scope conditions and variables. Content analysis may also be fruitful, but it is important to consider meaning and context. For example, a politician may use the term face but mean honor. Similarly, an activist may use the term dignity but mean honor as defined in this article.

\footnotetext{
${ }^{12}$ For what reason other than a genuine belief in human dignity do western countries support peacekeeping missions even though such missions hardly ever achieve their objectives and often turn out counterproductive (Greig and Diehl 2005)?
} 


\section{Intercultural IR}

So far, we have portrayed international relations (IR) among states sharing the same culture of self-worth. Let us now address international relations across cultures. What happens when the three cultural logics encounter each other in international relations? As we will see, relations between dignity and honor/face cultures are sufficiently similar to constitute one class, with relations between face and honor cultures constituting the other class.

\section{When dignity meets honor/face}

Relations between dignity cultures on the one hand, and honor and face cultures on the other, suffer from serious intercultural problems. This is hardly surprising given that honor and face cultures crave recognition in ways that are fundamentally different from dignity culture. Relations are particularly difficult and unstable when an honor culture perceives a problem of status anxiety. The same applies when a real or perceived humiliation has occurred, especially when the honor or face culture is the aggrieved party (Hypothesis 4). 


\section{Hypothesis 4: Relations between dignity and honor/face cultures}

a) Relations are difficult because it is hard for dignity cultures to grant honor and face cultures recognition on their own terms.

b) Relations are particularly difficult when an honor culture is troubled by status anxiety.

c) The same applies when humiliation has occurred, especially when an honor/face culture is the aggrieved party.

It is hard for dignity cultures to recognize the self-worth of honor and face cultures on the latter's own terms. Since dignity is about the intrinsic and inalienable self-worth of the individual, it is difficult from the vantage point of dignity culture to acknowledge self-worth established under the spell of honor or face. Dignity culture tends to be so individualistic that the very notion of collective and socially stratified self-worth becomes incomprehensible and morally suspicious. Accordingly, dignity cultures have little time for notions like national honor and face, contributing to fraught intercultural relations.

In part, this is a cognitive problem. The failure of western diplomats to appreciate the importance of honor and face for their non-western counterparts looms large in intercultural diplomacy (Cohen 1997). Like diplomats, western scholars have difficulties capturing the grammar of self-worth outside the west. Even when making a conscious effort to understand the need of honor and face cultures for recognition, they often create false symmetries by hypostasizing a universal idiom of recognition that fails to do justice to the specificities of honor and face. To cite just one example, a western scholar claims that the Taliban quest for recognition is equivalent to that of the west (Bell 2014). The problem with such a "balanced" representation is that it fails to appreciate that the Taliban have something different in mind 
when talking about recognition (for example, the right of Afghan men to rule over their womenfolk according to their own interpretation of tribal honor and sharia law).

As the Taliban example indicates, the problem is not merely cognitive. On the contrary, there are genuine normative differences between the cultural logics of dignity on the one hand, and honor/face on the other. The idea of intrinsic and inalienable dignity is incompatible with the way face cultures eclipse the individual. It is also incompatible with the way honor cultures draw a distinction between "honorable men” and others (frequently women) relegated to a life in dishonor and shame. Unsurprisingly, therefore, dignity cultures have a hard time recognizing privileged exponents of honor and face cultures on their own terms.

From a western perspective it is hard to understand, and even harder to accept, that honor and face cultures rank collective self-worth higher than the dignity, and sometimes even survival, of their citizens. Take for example the devastating famine during the period of China's "Great Leap”, from 1959 to 1961. At the time, Chinese officials refused to acknowledge the existence of the famine. Foreign Minister Chen Yi indignantly rejected western offers of assistance, saying that China would never "stoop to beg for food from the US" (cited in Ashton et al. 1984, 631). ${ }^{13}$ In 2008, still-autocratic Myanmar acted similarly in the aftermath of Cyclone Nargis, much to the bewilderment of western observers and activists.

Especially in the Chinese case, “face nationalism” (Gries 1999) leads to complications with the west. As Gries $(2004,114)$ puts it, “the phrase ‘to lose face for ...' (gei ... diulian) points to the responsibility Chinese have to maintain the face of the groups to which they belong. In international contexts, that group is the race-nation (minzu).” Dignity cultures are hardly willing to recognize "national face” on such blatantly collectivist terms. Instead, they insist on seemingly progressive causes such as free trade, human rights, or good governance. Precisely

\footnotetext{
${ }^{13}$ In 1959, when the famine was already serious, China increased exports, including of grain, to meet foreign obligations and impress the international public (Dikötter 2010, 78-83).
} 
because the promotion of such causes is more in line with western notions of dignity than with the collectivist logic of Chinese face culture, it further enrages the Chinese.

Are the problems mutual? It is certainly true that honor and face cultures have difficulties recognizing dignity, but this does not pose a problem because, given their individualistic nature, dignity cultures hardly claim national dignity in the first place. Problems may arise regarding the dignity of individuals, as for example when Singapore executes western tourists on drug trafficking offences or when Russia cracks down on western NGOs propagating human rights. Collectively, however, honor and face cultures can hardly offend dignity cultures because the latter fail to construct self-worth in collectivist terms.

Relations are particularly difficult and unstable when an honor culture perceives a problem of status anxiety. ${ }^{14}$ The paradigmatic case is Russia. For centuries, national honor has played an important role in Russia’s interactions with the west (Tsygankov 2012). As one author puts it, "Russian self-perception has always been one of Russia belonging to the great powers, but Russians at least feel that it has not been recognized as such by the west” (Smith 2014, 357). Even in Soviet times, the quest for superpower status and prickliness about lack of western respect were serious concerns (Ringmar 2002). In Putin’s Russia, this has again come to the surface (Forsberg, Heller, and Wolf 2014). The United States and its allies constantly disappoint “Russia’s desire to be recognized by the West not only as a power but as a legitimate system of values and institutions” (Tsygankov 2014, 351). Intercultural misunderstandings and Russian feelings of humiliation and resentment play an important role. According to one author, the ongoing conflict in Ukraine is the latest case in point (Tsygankov 2015).

Humiliation poses serious problems. In East Asia, too, where resentment due to the history of western imperialism continues. China ritualistically remembers a "Century of Humiliation"

\footnotetext{
${ }^{14}$ On the sensitivity of honor culture to status anxiety, see the related discussions above.
} 
when western powers were harassing the Middle Kingdom (Wang 2012; Miller 2013). ${ }^{15}$ Partly to overcome such trauma, China has become a relentless status seeker (Deng 2008). It is a formidable challenge for Washington to deal with Chinese demands for superpower status when "any attempt (...) to contain or limit Chinese power is seen as an unfair and aggressive attempt to subjugate China once again” (Murray 2015, 11; cf. Wang 2012, 163-201).

Similarly, Middle Eastern and African countries have emerged only recently from the experience of colonization and western imperialism. Muslim honor cultures feel further humiliated by the "War on Terror" in the wake of 9/11 (Ahmed 2003). Remarkably, not even the medieval crusades have faded from Islamic collective memory. In comparison, western remembrance of Al-Andalus in medieval Spain (711-1492), Saracen incursions into Italy during the same period, and the Ottoman sweep over the Balkans in the early modern era is remarkably mellow. As the theory predicts, it is considerably easier for dignity cultures than for honor or face cultures to set aside a history of humiliation. ${ }^{16}$

As journalist Thomas Friedman (2003) has put it, “If I’ve learned one thing covering world affairs, it's this: The single most underappreciated force in international relations is humiliation.” Sadly, even those in the west who have learnt this lesson often construct false symmetries, for example by depicting western humiliation of Muslims as the moral equivalent of jihadist attempts to humiliate the west by terrorist attacks (Saurette 2006; Fattah and Fierke 2009). Such false symmetries ignore crucial differences in meaning and intentionality. For

\footnotetext{
${ }^{15}$ Humiliation and shame are unavoidable companions of real or perceived loss of face, so much so that East Asian cultures are sometimes called "shame cultures," opposing them to western "guilt culture" (harking back to Benedict 2005 [1946], 222-227).

${ }^{16}$ Occasionally, the legacy of colonialism and imperialism unites developing countries in anti-western resentment. Since the 1955 Bandung Conference, a sense of shared victimhood has garnered political solidarity in the Global South. Aspirant developing-country leaders such as China and India have sometimes successfully exploited this. While understandable, it makes relations between developing countries and the west even more difficult.
} 
example, drone strikes are certainly traumatic for civilians in Middle Eastern countries but they do not intend to humiliate and defile civilians the way jihadist attacks do.

\section{When face meets honor}

Finally, let us come to relations between honor cultures on the one hand, and face cultures on the other. Given the logics of honor and face, these relations hinge on questions of relative status, with humiliation and resentment as another complicating factor (Hypothesis 5).

\section{Hypothesis 5: Relations between face and honor cultures}

a) When the face culture has higher status, relations tend to be positive and stable because face cultures respect the self-worth of inferiors.

b) Relations are more difficult and unstable in situations of symmetry because the honor culture may act aggressively due to status anxiety.

c) When the honor culture has higher status, lack of respect for the face culture may lead to humiliation and resentment, disrupting relations.

When the face culture has higher status, relations tend to be positive and stable because face cultures respect the self-worth of inferiors. Confident in its superior position, the face culture will massage the honor culture in such a way as to preserve social harmony. The relation may resemble the ancient tributary system of the Chinese empire, when ceremonialists at the imperial court could “'modestly’ refer to China as ‘our inferior country’ (biguo), fully confident 
of their actual superiority over tributary nations” (Gries 2004, 65). The outcome of such condescendence can be stable and harmonious relations (Kang 2010).

Take for example China's relations with the Middle East and Africa. While Chinese companies pursue business practices that are at least as neocolonial as the conduct of western corporations (resource extraction; unequal exchange), people in the Middle East and Africa perceive China as more respectful than the west. This is not limited to elites who obviously benefit from no-strings-attached Chinese aid, but also to the wider population where China enjoys considerable popularity (Pew 2015). Even the fact that China has “colonized” the vast Muslim-majority region of Xinjiang does not damage its reputation in the Middle East and Africa. In light of intercultural theory, the most likely reason is that China, as a face culture, shows greater respect than western dignity culture for lower-status honor cultures.

The advantage disappears in situations of rough symmetry because, under such circumstances, the honor culture is likely to experience status anxiety, destabilizing the relationship. Somewhat tragically, the honor culture may misinterpret the emphasis of the face culture on harmony as a sign of weakness, or even as a humiliating sign of condescendence. While appeasement by the face culture may lead to the appearance of positive relations in the short term, it may encourage the honor culture to engage in swaggering. The face culture may then have no other choice than to reassert its status by aggressively demonstrating resolve.

The early history of independent India and communist China is instructive in this regard. Both countries spent the 1950s reveling in their victimhood from western colonialism and imperialism, with Indian Prime Minister Nehru making it a point of honor to “mentor” other developing countries like China. By 1960, however, a conflict had emerged over disputed areas along the mountainous Chinese-Indian border. When China proposed a pragmatic and face-saving compromise, namely to trade sectors of the disputed territories, Nehru reassured 
Indian representatives that his government would not cave in to "national humiliation", and Indian diplomats dismissed the Chinese overture as false "reasonableness". This was despite the fact that the military balance at the time was stacked against India. In 1962, Beijing cut the Gordian knot by invading the disputed areas. After a demonstration of strength, China voluntarily withdrew from the eastern sector-exactly as it had offered two years earlier under the compromise proposal. Despite or precisely because of Chinese self-restraint, India cannot accept the outcome to the present day (Miller 2013, 54-81; Shankar 2015).

When the honor culture has higher status, resentment is almost destined to build up because honor cultures show little respect for the self-worth of inferiors. In such a situation, there is a risk that the honor culture may "lord it over" the face culture, with the latter building up resentment that may lead to an escalation of conflict as and when the opportunity arises.

While in the contemporary international system honor cultures hardly ever enjoy higher status than face cultures, the situation was different a century ago when western colonial powers were still acting as honor cultures. In China, anti-western resentment erupted in the Boxer Rebellion of 1899-1901. When seeing off a punitive expedition, German Emperor Wilhelm II addressed the departing sailors in a solemn speech, exhorting them to make sure that for a thousand years no Chinese would "dare so much as to look askance at a German” (Wilhelm 1904, 211). ${ }^{17}$ While this statement may appear extreme, other western countries including the USA, Britain, and France sent their own contingents to the punitive expedition. Needless to say, China remembers the expedition as the apogee of national humiliation.

\footnotetext{
${ }^{17}$ While some passages of the Hun Speech are of doubtful authenticity, all versions contain this expression. The English translation is borrowed from Prinz von Bülow (1932, 418). 


\section{Operationalization}

Tracking interactions between different cultures of self-worth is difficult but potentially rewarding. In principle, a researcher may operationalize intercultural IR in ways that are analogous to the operationalization of intra-cultural IR: behavioral indicators derived from the hypotheses; discursive markers gleaned from textual sources; and costly actions that are otherwise hard to explain. An additional possibility is tracking semantic translations that occur when notions of self-worth "travel” from one culture to another.

For example, when Juergensmeyer $(2008,219)$ interviewed Hamas leaders, one stated that the struggle of the intifada was “about honor” whereas another framed it in terms of "personal dignity”, pitching his message to his interlocutor’s western audience. Similarly, Mullah Omar claimed in 2009 that the Taliban were fighting for "universal human values, justice, peace, equal distribution of resources, and independence” (cited in Bell 2014, 538-539). In these cases, the sender of the message performed the translation, but it can also be the recipient. Thus, well-meaning western activists sometimes believe that jihadists struggle for dignity when these very jihadists view themselves as fighting for the honor of Islam.

\section{Levels of Analysis}

In this article, I have developed intercultural theory from the ground up, operating on the assumption that it is justifiable to scale up cultures of self-worth from groups of individuals to entire nations and states, and further to groupings of states. The transition from one level of analysis to another is always one of the most daunting maneuvers an IR scholar can undertake, so a systematic discussion of any problems arising will be in order. 
To begin with, I have assumed that states are beholden to self-worth in ways comparable to individuals acting in social groups. This assumption is hardly controversial if one considers the burgeoning bodies of literature discussed in the survey section. If collective self-worth did not exist, talk about international recognition, status, and reputation would be pointless. The same applies to culture-specific notions of corporate self-worth such as "national face” and especially "national honor" (see the Text Box in the section on "Three Cultures”).

Public and scholarly discourse aside, the case examples presented in this article confirms the practical utility of assuming that self-worth can be scaled up. Spatial constraints unfortunately do not allow me to belabor the point, but interested readers may turn to a book chapter persuasively making the case, by Wolf (2012). Overall, it seems perfectly reasonable to draw analogies between self-worth at the personal, group, national, and international level.

That said, the transition from the domestic to the national level does have its effects. Given the greater importance of status in honor culture, national honor is more likely to be an elite concern although it may sometimes offer identification to otherwise downtrodden popular masses. National face, by contrast, will always intensely cater to popular feelings of selfesteem, as one would expect given the communitarian nature of face. In other words, the mechanisms connecting domestic cultures to the decisions and actions of states and their leaders are to a large extent endogenous to each specific logic of self-worth.

Unlike an individual's claim for honor or face, a nation's claim rests on civic expectations and patriotic discourse. As a result, collectivities representing honor and face cultures act more alike than one would expect when looking at individuals. In fact, international relations 
among honor cultures are somewhat similar to international relations among face cultures, but very much unlike international relations among dignity cultures. ${ }^{18}$

Interestingly, the notion of "national dignity” is less common than "national honor" and "national face.” This is hardly surprising as the notion of dignity is individualistic, whereas honor and face are relational categories. Yet, dignity matters all the more for democratic leaders. They must take popular commitment to dignity into account, for example when promoting human rights or when trying to be inclusive towards refugees and immigrants.

At the level of international society (Bull 1977), IR combines features of all three cultures. The idea of great power status and related prerogatives such as permanent membership in the UN Security Council point to a system based on honor. Normative constructs like humanitarian intervention and, more recently, responsibility to protect point to a system based on dignity (Wheeler 2000). Diplomatic practices of ostentatious mutual deference point to a system based on face. Most recently, an author has found that saving face is important in as unlikely a domain as the state practice of covert military intervention (Carson 2016).

While it seems that international society shares a composite culture that loosely integrates it, pronouncements of the inexorable progression of liberal world culture seem overblown (Meyer et al. 1997). They represent little more than a projection of western dignity culture on the global stage, and they appear contingent on industrial capitalism and liberal hegemony (Morris 2015). If that is so, they may enter a reversal as and when these forces enter a decline. Variation inside international society between honor, face, and dignity cultures seems here to stay, especially if we imagine a gradual demise of the west and rise of the rest.

\footnotetext{
18 This becomes apparent when comparing Hypotheses 1 to 3, on intra-cultural IR. In Hypothesis 4, it was even possible to collapse honor and face. Yet, conceptually subtle but politically important differences between honor and face culture resurfaced in Hypothesis 5.
} 


\section{Conclusion}

The intercultural theory of international relations connects multiple levels of analysis, from individuals embedded in small-group settings via cultures of self-worth expressed at the national and regional level all the way up to entire civilizations and even beyond. ${ }^{19}$ The most important point of intercultural theory is that different cultures of self-worth constitute different dispositions, and these in turn constitute different logics of international relations. This is true for intercourse not only among members of the same culture but also across cultures.

Rooted in a framework derived from social and personality psychology, the theory is amenable to operationalization and yields countless observable implications that can be put to empirical scrutiny. Most importantly, the theory helps to understand contemporary international relations. It would be hard to understand the conflict between Russia and the west without appreciating the importance of honor for Russia and its leaders. It would be hard to understand the troubled relations between India and Pakistan without appreciating Pakistani status anxiety. It would be hard to understand the ongoing upheaval in the Middle East without appreciating the feelings of humiliation and resentment held by countless Muslims. On a positive note, China's popularity in Africa and the Middle East is at least partly due to the ostentatious respect Beijing shows to honor cultures of unquestionably lower status.

While the theory has been designed for intercultural relations among nations, it will be easy for scholars to find observable implications far beyond the confines of IR. Whenever groups sharing one culture of self-worth interact and/or encounter groups sharing another culture, the theory would predict a dynamic similar to the one outlined in this article. This may occur at

\footnotetext{
${ }^{19}$ Cultures of self-worth are broader than civilizations (Katzenstein 2010) because one culture of self-worth can encompass more than one civilization. For example, honor culture encompasses the Middle East, Africa, and South Asia. Face culture spans China and Japan.
} 
the domestic level, when different cultures of self-worth cohabit in a country. It may also happen transnationally, or in any other setting where cultures of self-worth interact.

Cultures of self-worth are certainly not set in stone. More than two and a half centuries ago, Montesquieu (1750) foresaw a transition from aristocratic honor to modern civility. For the next century or so, western “gentlemen” were still fighting duels (O'Neill 2003). The early twentieth century saw conflict between western countries professing allegiance to dignity, such as the USA under Woodrow Wilson, and others who were bent on turning the clock back to national honor. Over the 100 years since then, western cultures have come to see the very concept of honor as antiquated. Cultures are sticky, but change is possible.

Some non-western cultures are moving towards dignity, but this takes time and may be reversible. In the meanwhile, the west may have started another transformation. More and more westerners are dissatisfied with mere dignity and demand thick recognition for fancy personal identities, such as being a vegan transgender Buddhist. Others in the west demand recognition for communal identities, such as allegiance to the Islamic ummah. Another trend is for western society to grant the survivors of humiliation permanent status as traumatized victims, with violators relegated to perpetual contumely. How might this affect international relations? Post-war Israel and Germany come to mind. As it stands, international society puts limits to Israel's claim for special status as a victim. Despite periodic flagellations, Germany has been able to reoccupy a dignified role. What will happen in similar cases in the future, should western culture lose its astounding capacity for reconciliation and reintegration?

Let me end this article on a cautionary note. Self-worth is not always and not necessarily a good thing. To be sure, it is appealing from a post-materialist perspective. It is somewhat uplifting to think that the fountainhead of international relations is not so much lust for power (animus dominandi) or the pursuit of gain (homo oeconomicus) but rather the strive for self- 
worth. In reality, of course, the struggle for recognition brings out not only the best but also the worst in people. From the viewpoint of a stoic philosopher, self-worth has something shallow and, well, selfish about it. Most religious traditions, Christianity included, leave no doubt that self-surrender is the ultimate sacrifice and the ultimate triumph.

\section{Acknowledgments}

The author would like to thank Jacob Barandes, Ryan Berg, Adriana Bianco, Jennifer Erickson, Kerstin Friedrichs, John Gledhill, Douglas Johnston, Friedrich Kratochwil, Martin Kraus, Gianfranco Poggi, Christian Reus-Smit, Duncan Snidal, Scott Thomas, Alexander Wendt, Reinhard Wolf, Xiaoying Qi, and the three anonymous reviewers of International Theory for critical comments and helpful suggestions. 


\section{Reference list}

Agné, Hans, Jens Bartelson, Eva Erman, Thomas Lindemann, Benjamin Herborth, Oliver Kessler, Christine Chwaszcza, Mikulas Fabry, and Stephen D. Krasner, eds. 2013. Symposium: 'The politics of international recognition'. International Theory 5 (1):94176.

Ahmed, Akbar S. 2003. Islam Under Siege: Living Dangerously in a Post-Honor World. Cambridge: Polity.

Ashton, Basil, Kenneth Hill, Alan Piazza, and Robin Zeitz. 1984. Famine in China, 1958-61. Population and Development Review 10 (4):613-645.

Aslani, Soroush, Jimena Ramirez-Marin, Zhaleh Semnani-Azad, Jeanne M. Brett, and Catherine Tinsley. 2013. Dignity, face, and honor cultures: implications for negotiation and conflict management. In Handbook of Research on Negotiation, edited by M. Olekalns and W. L. Adair. Cheltenham: Edward Elgar, 249-282.

Ayers, Edward L. 1984. Vengeance and Justice: Crime and Punishment in the 19th-Century American South. New York: Oxford University Press.

Bell, Arvid. 2014. The roadblock of contested recognition: identity-based justice claims as an obstacle to peace negotiations in Afghanistan. International Negotiation 19 (3):518542.

Benedict, Ruth. 2005 [1946]. The Chrysanthemum and the Sword: Patterns of Japanese Culture. Boston: Mariner.

Berger, Peter. 1970. On the obsolescence of the concept of honor. European Journal of Sociology 11 (2):339-347.

Best, Geoffrey. 1982. Honor Among Men and Nations: Transformations of an Idea. Toronto: University of Toronto Press.

Bowman, James. 2012. Honor: A History. New York: Encounter.

Brincat, Shannon, ed. 2014. Recognition, conflict and the problem of ethical community [special issue]. Global Discourse 4 (4).

Bull, Hedley. 1977. The Anarchical Society: A Study of Order in World Politics. Basingstoke: Macmillan.

Carson, Austin. 2016. Facing off and saving face: covert intervention and escalation management in the Korean War. International Organization (forthcoming).

Cohen, Raymond. 1997. Negotiating Across Cultures: International Communication in an Interdependent World. 2nd ed. Washington, DC: United States Institute of Peace Press.

Daase, Christopher, Caroline Fehl, Anna Geis, and Georgios Kolliarakis, eds. 2015. Recognition in International Relations: Rethinking a Political Concept in a Global Context. Basingstoke: Palgrave Macmillan.

Dafoe, Allan, Jonathan Renshon, and Paul Huth. 2014. Reputation and status as motives for war. Annual Review of Political Science 17:371-393.

Delori, Mathias. 2014. Killing without hatred: the politics of (non)recognition in contemporary Western wars. Global Discourse 4 (4):516-531.

Demetriou, Daniel. 2013. Honor war theory: romance or reality? Philosophical Papers 42 (3):285-313.

Deng, Yong. 2008. China's Struggle for Status: The Realignment of International Relations. Cambridge: Cambridge University Press.

Dikötter, Frank. 2010. Mao's Great Famine: The History of China's Most Devastating Catastrophe, 1958-62. London: Bloomsbury.

Donelan, Michael. 2007. Honor in Foreign Policy: A History and Discussion. New York: Palgrave Macmillan. 
Erickson, Jennifer L. 2014. Saving face, looking good, and building international reputation in east and west. In Power in a Complex Global System, edited by L. W. Pauly and B. W. Jentleson. London and New York: Routledge, 180-193.

Fair, C. Christine. 2014. Fighting to the End: The Pakistan Army's Way of War. New York: Oxford University Press.

Fassin, Didier. 2013. On resentment and ressentiment: the politics and ethics of moral emotions. Current Anthropology 54 (3):249-267.

Fattah, Khaled, and K.M. Fierke. 2009. A clash of emotions: the politics of humiliation and political violence in the Middle East. European Journal of International Relations 15 (1):67-93.

Finley, Moses I. 1954. The World of Odysseus. New York: Viking.

Forsberg, Tuomas, Regina Heller, and Reinhard Wolf. 2014. Status and Emotions in Russian Foreign Policy [Special Issue]. Communist and Post-Communist Studies 47 (3).

Friedman, Thomas L. 2003. The humiliation factor. New York Times, 9 November.

Friedman, Yohanan. 2003. Tolerance and Coercion in Islam: Interfaith Relations in the Muslim Tradition. Cambridge: Cambridge University Press.

Fry, Joseph A. 2002. Dixie Looks Abroad: The South and U.S. Foreign Relations, 1797-1973. Baton Rouge: Louisiana State University Press.

Fukuyama, Francis. 1992. The End of History and the Last Man. London: Penguin.

Goffman, Erving. 1955. On face-work: an analysis of ritual elements in social interaction. Psychiatry: Journal for the Study of Interpersonal Processes 18 (3):213-231.

-----. 1967. Interaction Ritual: Essays on Face-to-Face Behaviour. Chicago: Aldine.

Gould, Roger V. 2003. Collision of Wills: How Ambiguity about Social Rank Breeds Conflict. Chicago: University of Chicago Press.

Greenhill, Brian. 2008. Recognition and collective identity formation in international politics. European Journal of International Relations 14 (2):343-368.

Greig, J. Michael, and Paul Diehl. 2005. The peacekeeping-peacemaking dilemma. International Studies Quarterly 49 (4):621-645.

Gries, Peter Hays. 1999. A "China threat"? Power and passion in Chinese "face nationalism". World Affairs 162 (2):63-75.

-----. 2004. China's New Nationalism: Pride, Politics, and Diplomacy. Berkeley: University of California Press.

Gurr, Ted Robert. 1970. Why Men Rebel. Princeton, NJ: Princeton University Press.

Gustafsson, Karl. 2015. Identity and recognition: remembering and forgetting the post-war in Sino-Japanese relations. Pacific Review 28 (1):117-138.

Haacke, Jürgen. 2005. The Frankfurt School and International Relations: on the centrality of recognition. Review of International Studies 31 (1):181-194.

Hahn, Jee-Won, and Hunter Hatfield. 2011. Group face in Korea and the United States: taking responsibility for the individual and the group. Multilingua 30 (1):25-70.

Hatfield, Hunter, and Jee-Won Hahn. 2014. The face of others: triadic and dyadic interactions in Korea and the United States. Journal of Politeness Research 10 (2):221-245.

He, Ming, and Shao-jie Zhang. 2011. Re-conceptualizing the Chinese concept of face from a face-sensitive perspective. Journal of Pragmatics 43 (9):2360-2372.

Hegel, Georg Wilhelm Friedrich. 1807. Die Phänomenologie des Geistes. Bamberg: Goebhardt.

Ho, David Yau-fai. 1976. On the concept of face. American Journal of Sociology 81 (4):867884.

Hoffmann, Stanley. 1968. Gulliver's Troubles, or the Setting of American Foreign Policy. New York: McGraw-Hill.

Honneth, Axel. 1995. The Struggle for Recognition: The Moral Grammar of Social Conflicts. Cambridge: Polity. 
-----. 2012. The I in We: Studies in the Theory of Recognition. Cambridge: Polity. Hu, Hsien Chin. 1944. The Chinese concepts of "face". American Anthropologist 46 (1):4564.

Iliffe, John. 2005. Honour in African History. Cambridge: Cambridge University Press. Jaffrelot, Christophe. 2011. Religion, Caste, and Politics in India. London: Hurst.

Juergensmeyer, Mark. 2008. Global Rebellion: Religious Challenges to the Secular State, from Christian Militias to Al Qaeda. Berkeley: University of California Press.

Kádár, Dániel Z., Michael Haugh, and Wei-Lin Melody Chang. 2013. Aggression and perceived national face threats in Mainland Chinese and Taiwanese CMC discussion boards. Multilingua 32 (3):343-372.

Kang, David C. 2010. East Asia Before the West: Five Centuries of Trade and Tribute. New York: Columbia University Press.

Katzenstein, Peter J. 2005. A World of Regions: Asia and Europe in the American Imperium. Ithaca, NY: Cornell University Press.

-----, ed. 2010. Civilizations in World Politics: Plural and Pluralist Perspectives. London and New York: Routledge.

Kelly, Robert E. 2011. A 'Confucian Long Peace' in pre-Western East Asia? European Journal of International Relations 18 (3):407-430.

Kim, Joo Yup, and Sang Hoon Nam. 1998. The concept and dynamics of face: implications for organizational behavior in Asia. Organization Science 9 (4):522-534.

Kim, Young-Hoon, and Dov Cohen. 2010. Information, perspective, and judgments about the self in face and dignity cultures. Pesonality and Social Psychology Bulletin 36 (4):537-550.

Kim, Young-Hoon, Dov Cohen, and Wing-Tung Au. 2010. The jury and abjury of my peers: the self in face and dignity cultures. Journal of Personality and Social Psychology 98 (6):904-916.

Larson, Deborah Welch, and Alexei Sevchenko. 2010. Status seekers: Chinese and Russian responses to U.S. primacy. International Security 34 (4):63-95.

Lebow, Richard Ned. 2008. A Cultural Theory of International Relations. Cambridge: Cambridge University Press.

-----. 2010. Why Nations Fight: Past and Future Motives for War. New York: Cambridge University Press.

-----. 2015. Thumos, war, and peace. Common Knowledge 21 (1):50-82.

Lee, Hae In, Angela K-Y. Leung, and Young-Hoon Kim. 2014. Unpacking east-west differences in the extent of self-enhancement from the perspective of face versus dignity culture. Social and Personal Psychology Compass 8 (7):314-327.

Leung, Angela K.-Y, and Dov Cohen. 2011. Within- and between-culture variation: individual differences and the cultural logics of honor, face, and dignity cultures. Journal of Personality and Social Psychology 100 (3):507-526.

Lindemann, Thomas. 2010. Causes of War: The Struggle for Recognition. Colchester: ECPR Press.

-----. 2014. Interest, passion, (non)recognition, and wars: a conceptual essay. Global Discourse 4 (4):483-496.

Lindemann, Thomas, and Erik Ringmar, eds. 2012. The International Politics of Recognition. Bolder, CO: Paradigm.

Meyer, John W., John Boli, George M. Thomas, and Francisco O. Ramirez. 1997. World Society and the Nation State. American Journal of Sociology 103 (1):144-179.

Miller, Manjari Chatterjee. 2013. Wronged by Empire: Post-Imperial Ideology and Foreign Policy in India and China. Stanford: Stanford University Press.

Montesquieu, Charles de Secondat, Baron de. 1750. The Spirit of Laws. London: Printed for J. Nourse and P. Vaillant. 
Morisaki, Seiichi, and William B. Gudykunst. 1994. Face in Japan and the United States. In The Challenge of Facework: Cross-Cultural and Interpersonal Issues, edited by S. Ting-Toomey. New York: SUNY Press, 47-93.

Morris, Ian. 2015. Foragers, Farmers, and Fossil Fuels: How Human Values Evolve. Princeton, NJ: Princeton University Press.

Murray, Michelle. 2015. Recognizing Rising Powers: China's Rise and U.S. Foreign Policy. Paper presented at the Annual Convention of the International Studies Association, New Orleans, February 18-21.

Nayar, Baldev Raj, and T.V. Paul. 2003. India in the World Order: Searching for MajorPower Status. Cambridge: Cambridge University Press.

Nietzsche, Friedrich. 1994 [1887]. On the Genealogy of Morality. Cambridge: Cambridge University Press.

Nisbett, Richard E., and Dov Cohen. 1996. Culture of Honor: The Psychology of Violence in the South. Boulder, CO: Westview.

Nwoye, Onuigbo G. 1992. Linguistic politeness and socio-cultural variations of the notion of face. Journal of Pragmatics 18 (4):309-328.

O'Neill, Barry. 1999. Honor, Symbols, and War. Ann Arbor: University of Michigan Press.

-----. 2003. Mediating national honour: lessons from the era of dueling. Journal of Institutional and Theoretical Economics 159 (1):229-247.

Oldmeadow, Julian A., and Susan T. Fiske. 2012. Contentment to resentment: variation in stereotype content across status systems. Analyses of Social Issues and Public Policy 12 (1):324-339.

Onea, Tudor A. 2014. Between dominance and decline: status anxiety and great power rivalry. Review of International Studies 40 (1):125-152.

Paul, T.V., Deborah Welch Larson, and William C. Wohlforth, eds. 2014. Status in World Politics. New York: Cambridge University Press.

Paul, T.V., and Manesh Shankar. 2014. Status accommodation through institutional means: India's rise and the global order. In Status in World Politics, edited by T. V. Paul, D. W. Larson and W. C. Wohlforth. New York: Cambridge University Press, 165-191.

Péristiany, John G., ed. 1966. Honour and Shame: The Values of Mediterranean Society. Chicago: University of Chicago Press.

Perla, Leo. 1918. What is "National Honor". New York: Macmillan.

Pew. 2015. Global Publics Back U.S. on Fighting ISIS, but Are Critical of Post-9/11 Torture. Washington, DC: Pew Research Center.

Pitt-Rivers, Julian. 1965. Honour and social status. In Honour and Shame: The Values of Mediterranean Society, edited by J. G. Péristiany. London: Weidenfeld and Nicolson, 19-77.

Prinz von Bülow. 1932. Memoirs of Prince von Bülow: From Secretary of State to Imperial Chancellor, 1897-1903. Boston: Little, Brown, and Company.

Qi, Xiaoying. 2011. Face: a Chinese concept in a global sociology. Journal of Sociology 47 (3):279-295.

Renshon, Jonathan. 2016. Status deficits and war. International Organization (forthcoming).

Ringmar, Erik. 1996. Identity, Interest and Action: A Cultural Explanation of Sweden's Intervention in the Thirty Years War. Cambridge: Cambridge University Press.

-----. 2002. The recognition game: Soviet Russia against the west. Cooperation and Conflict 37 (2):115-136.

Robinson, Paul. 2006. Military Honour and the Conduct of War: From Ancient Greece to Iraq. London and New York: Routledge.

Sauder, Michael, Freda Lynn, and Joel M. Podolny. 2012. Status: insights from organizational sociology. Annual Review of Sociology 38:267-283. 
Saurette, Paul. 2006. You dissin me? Humiliation and post 9/11 global politics. Review of International Studies 32 (3):495-522.

Scheler, Max. 1994 [1912]. Ressentiment. Milwaukee, WI: Marquette University Press.

Schumpeter, Joseph A. 1951. Imperialism and Social Classes. New York: Kelley.

Searle, John R. 2010. Making the Social World: The Structure of Human Civilization. Oxford: Oxford University Press.

Shankar, Manesh. 2015. Showing character: Nehru, reputation, and the Sino-Indian dispute, 1957-1962. Asian Security 11 (2):99-115.

Smith, Hanna. 2014. Russia as a great power: status inconsistency and the two Chechen wars. Communist and Post-Communist Studies 47 (3):355-363.

Smith, Nicholas H., and Shane O'Neill. 2012. Recognition Theory as Social Research: Investigating the Dynamics of Social Conflict. Basingstoke: Palgrave Macmillan.

Solingen, Etel. 1998. Regional Orders at Century's Dawn: Global and Domestic Influences on Grand Strategy. Princeton, NJ: Princeton University Press.

Stewart, Frank Henderson. 1994. Honor. Chicago: University of Chicago Press.

Taylor, Charles. 1994. The politics of recognition. In Multiculturalism: Examining the Politics of Recognition, edited by A. Gutmann. Princeton, NJ: Princeton University Press, 25-73.

Tsygankov, Andrei P. 2012. Russia and the West from Alexander to Putin: Honor in International Relations. Cambridge: Cambridge University Press.

-----. 2014. The frustrating partnership: honor, status, and emotions in Russia's discourses of the West. Communist and Post-Communist Studies 47 (3):345-354.

-----. 2015. Vladimir Putin's last stand: the sources of Russia's Ukraine policy. Post-Soviet Affairs 31 (4):279-303.

Ure, Michael. 2015. Resentment/ressentiment. Constellations (forthcoming).

Vandello, Joseph A., Dov Cohen, and Sean Ransom. 2008. U.S. Southern and Northern differences in perceptions of norms about aggression: mechanisms for the perpetuation of a culture of honor. Journal of Cross-Cultural Psychology 39 (2):162177.

Volgy, Thomas J., Renato Corbetta, Keith A. Grant, and Ryan Baird, eds. 2011. Major Powers and the Quest for Status in International Politics: Global and Regional Perspectives. Basingstoke: Palgrave Macmillan.

Wang, Zheng. 2012. Never Forget National Humiliation: Historical Memory in Chinese Politics and Foreign Relations. New York: Columbia University Press.

Weiner, Mark S. 2013. The Rule of the Clan: What an Ancient Form of Social Organization Reveals about the Future of Individual Freedom. New York: Farrar, Straus and Giroux.

Wendt, Alexander. 2003. Why a world state is inevitable. European Journal of International Relations 9 (4):491-542.

Wheeler, Nicholas J. 2000. Saving Strangers: Humanitarian Intervention in International Society. Oxford: Oxford University Press.

Wilhelm. 1904. Die Reden Kaiser Wilhelms II. in den Jahren 1896-1900. Leipzig: Reclam.

Wohlforth, William C. 2009. Unipolarity, status competition, and great power war. World Politics 61 (1):28-57.

Wolf, Reinhard. 2011. Respect and disrespect in international politics: the significance of status recognition. International Theory 3 (1):105-142.

-----. 2012. Prickly states? Recognition and disrespect between people and states. In The International Politics of Recognition, edited by T. Lindemann and E. Ringmar. Boulder, CO: Paradigm, 39-56.

-----. 2013. Resentment in International Relations. Paper presented at the ECPR Workshop on Status Claims, Recognition, and Emotions in IR, Mainz, March 11-16. 
-----. 2015. Respecting foreign peoples: the limits of moral obligations. Journal of International Relations and Development (forthcoming).

Wyatt-Brown, Bertram. 1982. Southern Honor: Ethics and Behaviour in the Old South. New York: Oxford University Press.

-----. 2005. The ethic of honor in national crises: the Civil War, Vietnam, Iraq, and the Southern factor. Journal of the Historical Society 5 (4):431-460.

Yongjin, Zhang, and Barry Buzan. 2012. The tributary system as international society in theory and practice. Chinese Journal of International Politics 5 (3-36). 